\title{
PENDIDIKAN AKHLAQ \\ PERSPEKTIF PEMIKIRAN IBNU MISKAWAIH \\ (TOKOH FILOSOF MUSLIM MASA ABAD TENGAH)
}

\author{
Ifa Afidah \\ Fakultas Tarbiyah, IAI Al - Falah As - sunniyyah Kencong \\ Ifa.87aza@gmail.com
}

\begin{abstract}
Ibn Miskawaih's thoughts on Akhlaq's education will continue to be an incredible contribution to the Islamic education format, both in the past, in the present and in the future. His ideas were born from the efforts of combining Islamic doctrine with the views of Greek philosophers, according to Ibn Miskawaih, morals or morals is a mental attitude (a liar) which contains the impetus to do without thought and consideration. This mental attitude is divided into two, some are derived from the character and some are derived from practice. Thus, it is very important to uphold the true character, because with such a foundation, will produce good deeds without difficulty.
\end{abstract}

Keyword:Akhlaq's education, Ibnu Miskawaih

\begin{abstract}
Pemikiran Ibnu Miskawaih tentang pendidikan Akhlaq akan terus menjadi sumbangan luar biasa terhadap format pendidikan yang Islami, baik dimasa lalu, masa sekarang dan masa yang akan datang. Gagasan- gagasannya lahir dari usaha menggabungkan doktrin Islam dengan pendapat filusuf Yunani, menurut Ibnu Miskawaih, moral atau akhlak adalah suatu sikap mental (halun li an- nafs) yang mengandung daya dorong untuk berbuat tanpa berfikir dan pertimbangan. Sikap mental ini terbagi dua, ada yang berasal dari watak dan ada pula yang berasal dari latihan. Dengan demikian, sangat penting menegakkan akhlak yang benar, sebab dengan landasan yang begitu, akan melahirkan perbuatan- perbuatan baik tanpa kesulitan.
\end{abstract}

Kata Kunci: Pendidikan Akblak, Ibnu Miskawaih

\section{PENDAHULUAN}

Misi utama agama Islam salah satunya adalah untuk menyempurnakan akhlak manusia. Dengan misi itu manusia diharapkan menjadi makhluk yang 
bermoral, yakni mahkluk yang bertanggung jawab sepenuhnya atas segala perbuatan yang dipilihnya dengan sadar, yang saleh maupun yang jahat. Akblak al Karimah yang diajarkan dalam Islam merupakan orientasi yang harus dipegang oleh setiap muslim. ${ }^{1}$ Seseorang yang hendak memperoleh kebahagiaan sejati (alsa'adah alhaqiqjyah), hendaknya menjadikan akhlak sebagai landasan dalam bertindak dan berperilaku. Sebaliknya, orang yang tidak memperdulikan pembinaan akhlak adalah orang yang tidak memiliki arti dan tujuan hidup.

Pembinaan akhlak sangat terkait kepada dua unsursubstansial dalam diri manusia yaitu jiwa dan jasmani denganbudi pekerti yang baik, berarti juga mengisi perilaku dantindakan mulia yang dapat dimanifestasikan oleh jasmani ataudengan kata lain, budi pekerti yang terdapat di dalam jiwaturut mempengaruhi keutamaan pribadi seseorang. Olehkarena itu, akhlak harus dijadikan sebagai orientasi hidup disetiap masa dan waktu. Letak pentingnya pembinaan akhlakdapat dilihat dalam firman Allah dalam Al-Qur'an yang artinya:

"Sesungguhnya telah ada pada (diri) Rasulullah itu suriteladan yang baik bagimu (yaitu) bagi orang yang mengharap(rahmat) Allah dan (kedatangan) hari kiamat dan Dia banyakmenyebut Allah"2 (Q.S. al-Ahzab : 21)

Pada masa pemerintahan Harun al-Rasyid tahun 786 M, di zaman Daulah Bani Abbasiyah, dikenal sebagai figure cinta kepada ilmu pengetahuan, sehingga buku-buku Yunani banyak yang diterjemahkan kedalam bahasa Arab. Buku-buku yang diterjemahkan adalah buku yang memuat pengetahuan tentang kedokteran, ilmu pengetahuan dan filsafat seperti buku-buku Aristoteles, Plato dan Gaelan. ${ }^{3}$

Dari usaha yang ditekuni oleh khalifah tersebut, timbullah minat orangorang Islam untuk mempelajari bermacam-macam ilmu pengetahuan dan filsafat. Maka muncullah para cendekiawan dan filosof dikalangan umat Islam seperti alKindi, al-Farabi, Ibnu Sina, al-Razi termasuk Ibnu Maskawaih yang terkenal dgn filsafat al-Nafs dan filsafat al-Akblak.

Ibnu Miskawaih adalah tokoh fenomenal masa abad tengah yang menggeluti bidang akhlak. Usaha Miskawaih adalah mempertemukan ajaran syariat islam dengan teori- teori etika dalam filsafat. Ibnu Miskawaih memberikan

\footnotetext{
${ }^{1}$ Nurkhalis Madjid, Islam Doktrin dan Peradaban, (Jakarta: Paramadina, 2008), hlm. 6 .

${ }^{2}$ Depag RI, Alquran dan Terjemahan, (Jakarta; Pt. Sygma Examedia Arkanleema, 2009)

${ }^{3}$ Harun Nasution, Filsafat dan Mistisisme dalam Islam (Jakarta: Bulan Bintang, 1973), hlm. 11.
}

18 | FaLASIFA, Vol. 10 Nomor 1 Maret 2019 
pengertian karakter (khuluk) adalah keadaan jiwa seseorang yang mendorong untuk melakukan sesuatu perbuatan tanpa melalui pertimbangan fikiran terlebih dahulu. Tujuan pendidikan akhlak yang dirumuskan oleh Ibnu Miskawaih adalah terwujudnya sikap batin yang mampu mendorong secara spontan untuk melahirkan semua perbuatan yang bernilai baik sehingga dapat mencapai kesempurnaan dan memperoleh kebahagiaan sejati dan sempurna.

Banyaknya karya- karya Ibnu Miskawaih dan pemikiran yang mendalam pada bidang akhlak, menjadikan daya tarik tersendiri bagi penulis untuk mengkaji dan menelaah tentang pemikiran Ibnu Miskawaih dalam pendidikan akhlak.

\section{PENDAHULUAN}

\section{BIOGRAFI IBNU MISKAWAIH}

Nama Lengkap Ibnu Miskawaih adalah Abu Ali Al Khazin Ahmad Ibnu Ya'kub Miskawaih, nama sebutannya yang lebih mashur adalah Miskawaih atau Ibnu Miskawaih. ${ }^{4}$ Nama Miskawaih diambil dari kakeknya. Kakeknya semula beragama Majusi kemudian masuk Islam. Gelarnya adalah Abu Ali yang diperoleh dari nama sahabat Ali, yang bagi kaum Syi "eah dipandang sebagai seorang yang berhak menggantikan Nabi dalam kedudukannya sebagai pemimpin umat Islam setelahnya. Dengan adanya gelar ini, maka kebanyakan orang mengatakan bahwa ia adalah penganut Syieeah. Sedangkan gelar al-Khazim yang berarti bendaharawan diberikan kepadanya karena ia memperoleh kepercayaan sebagai bendaharawan dimasa kepemimpinan Adid al-Daulah dari Bani Buwaih. ${ }^{5}$

Selain itu gelar guru ketiga setelah al- Farabi juga ditabalkan kepada Ibnu Miskawaih, seorang ilmuwan agung kelahiran Rayy, Persia (sekarang Iran) sekitar tahun $320 \mathrm{H} / 932 \mathrm{M}$. Ia merupakan seorang ilmuwan hebat, bahkan ia juga dikenal sebagai seorang filsuf, penyair, dan sejaraan yang sangat terkenal. ${ }^{6}$

Pendidikan Ibnu Miskawaih tidak berbeda dari kebiasaan anak menuntut ilmu pada masanya, yaitu bermula dengan belajar membaca, menulis, mempelajari al- qur'an dan dasar-dasar bahasa Arab, Nahwu dan Arrudh (Ilmu membaca dan menulis syair), Mata pelajaran dasar tersebut diberikan di surau-surau. Setelah Ilmu dasar ilmu itu diberikan, anak-anak baru diberikan pelajaran ilmu fiqh, hadist, Sejarah (Persi, Arab, dan India), Matematika juga ilmu praktis seperti musik, bermain catur dan furusiah (Kemiliteran). Meskipun Ibnu Miskawaih tidak

\footnotetext{
${ }^{4}$ Abdul Mujib dan Muhaimin Tadjab, Dimensi Studi Islam, (Surabaya : Abdi Tama, 1994),hlm. 302

${ }^{5}$ Maftuhin, Filsafat Islam, (Yogyakarta: Teras, 2012), hlm. 115-117.

${ }^{6}$ https://www.google.com/amp/s/m.republika.co.id/amp/52731 tentang Ibnu Miskawaih, bapak etika Islam (28 mei 2009)
} 
Ifa Afidah

mengikuti pelajaran privat karena ekonomi keluarga yang tidak mampu untuk mendatangkan guru terutama untuk pelajaran lanjut yang biayanya mahal. Perkembangan ilmu Ibnu Miskawaih diperoleh melalui jalan membaca buku pada saat menjadi pustakawan Ibn Al Amid, Menteri Rukn Al Daulah yang akhirnya menjadi bendaharawan Adhud Al Daulah. ${ }^{7}$

Ia terlahir pada era kejayaan Kekhalifahan Abbasiyyah. Sejarah mencatat bahwa Ibnu Miskawaih melewatkan seluruh masa hidupnya pada masa kekhalifahan Abbasiyyah yang berlangsung selama 524 tahun, yaitu dari tahun 132 sampai 654 H/ 750-1258 M. ${ }^{8}$ Ibnu Miskawaih meninggalkan Rayy menuju Baghdad dan mengabdi kepada istana pangeran Buwaihi sebagai bendaharawan dan beberapa jabatan lain. Dia mengkombinasikan karier politik dengan peraturan filsafat yang penting. Tak hanya dikantor Buwaihi di Baghdad, ia juga mengabdi di Isfahan dan Rayy. Akhir hidupnya banyak dicurahkannya untuk menulis. ${ }^{9}$

Ibnu Miskawaih lebih dikenal sebagai filsuf akhlak (etika) walaupun perhatiannya luas meliputi ilmu-ilmu yang lain seperti kedokteran, bahasa, sastra dan sejarah. Bahkan dalam literatur filsafat Islam, tampaknya hanya Ibnu Miskawaih inilah satu-satunya tokoh filsafat akhlak.

\section{PEMIKIRAN IBNU MISKAWAIH TENTANG PENDIDIKAN}

\section{AKHLAQ}

\section{Karya- Karya Ibnu Miskawaih}

Ibnu Miskawaih tidak hanya dikenal sebagai seorang pemikir (filosof). Tetapi ia juga seorang penulis yang produktif. ${ }^{10}$ Adapun diantara karya tulis Ibnu Miskawaih dalam Syarif yang dikutip Sirojuddin Zar adalah: ${ }^{11}$

a. Al-Fauzal-Akbar

b. Al-Fauzal-Asghar

c. Tajaribul Umam (sebuah sejarah tentang banjir besar yang ditulisnya pada tahun $369 \mathrm{H} / 979 \mathrm{M}$ )

d. Uns al-Farid (koleksi anekdot, syair, peribahasa: dan kata- kata hikmah)

\footnotetext{
${ }^{7}$ Nisrokha, Membongkar Konsep Pendidikan Akblak Ibnu Miskawaih, Jurnal Madaniyah, Volume I Edisi X Januari 2016, hlm. 109

${ }^{8}$ Ary Nilandari, Memahat Kata, Memugar Dunia:101 Kisah yang Menggugah

Pikiran, (Bandung: Penerbit MLC, 2005), hlm. 42-46

${ }^{9}$ https://www.google.com/amp/s/m.republika.co.id/amp/52731 tentang Ibnu Miskawaih...

${ }^{10}$ M.M. Syarif, (Ed.), The History of Muslim Philosophy, ( New York: Dover Publications, 1967), hlm. 469

${ }^{11}$ Sirojuddin Zar, Filsafat Islam (Filosof dan Filsafatnya), (Jakarta: Rajawali Press, 2017), hlm.132-133
}

20 | FaLASIFA, Vol. 10 Nomor 1 Maret 2019 
e. Tartib al-saadat (isinya akhlak dan politik).

f. Al-Mustanfa (isinya syair- syair pilihan)

g. Jawidan Khirad (koleksi ungkapan bijak)

h. Al-Jami'

i. Al-Siyab

j. On the Simple Drugs (tentang kedokteran)

k. On the Compisition of the Bajats (seni memasak)

1. Kitab al-Ashribah (tentang minuman)

m. Tabdzib al-Akblak (tentang Akhlak)

n. Risalat fi al-lazzat wa al-alam fi Jaubar al-Nafs

o. Ajwibat wa As' ilat fi al-Nafs wa al-Aql

p. Al-Jawab fi al-Masail al-Salas

q. Risalat fi Jawab fi Su'al Ali ibn Mubammad Abu Hayyan al- Shufi fi Haqiqat alAql.

r. Thabarat al-Nafs.

Ibnu Miskawaih memiliki banyak kitab yang membahas tentang akhlak, dan yang paling terkenal adalah Tabdzib al- Akblaq.Diawal muqaddimah, Ibnu Miskawaih menjelaskanbahwa pentingnya kitab Tahdzib al-Akblak dijadikan sebagaipegangan dalam pembinaan akhlak. Ia menjelaskan bahwa tujuanbuku ini ditulis adalah untuk menghasilkan moral dalam diri yangnantinya akan menjadi sumber dari perbuatan-perbuatan yangseluruhnya adalah perbuatan yang baik atau indah, mudah untukdilakukan, bukan karena dibuat-buat atau dipaksa, semua tingkahlaku itu dapat dicapai melalui suatu perekayasaan dan pendidikanyang sistematis. Dengan demikian, dapat kita ketahui bahwamenurut Ibnu Miskawaih pendidikan akhlak dapat dibina denganlatihan-latihan atau pembiasaanpembiasaan. ${ }^{12}$

Kitab Tabdzibul akblak berisikan tujuh bab, bab pertamadimulai dengan membahas mengenai jiwa, karena jiwa merupakanpusat tempat timbulnya akhlak; bab kedua membahas tentangakhlak, di bab ini Ibnu Miskawaih memulainya dengan penegasandefinisi dari akhlak itu sendiri, kemudian ada pembahasan tentangfitrah manusia; bab ketiga membahas bagian utama dari akhlakyakni kebaikan dan keburukan serta kebahagiaan; bab keempatmembahas tentang keutamaan yang memuat masalah keadilan;bab kelima berbicara mengenai cinta dan persahabatan; dua babterakhir membahas tentang kesehatan jiwa dan penyembuhanpenyakit jiwa. hlm. 14.

${ }^{12}$ Ibnu Miskawaih, Tahdzib al-Akblak, (Beirut : Darul al-Kutub al-Ilmiah, 1985),

FaLASIFA, Vol. 10 Nomor 1 Maret 2019 | 21 
Ifa Afidah

\section{Akhlak Menurut Ibnu Miskawaih}

Pemikirannya tentang ilmu akhlaq mempunyai hubungan dengan ilmu Filsafat. Pengertian ilmu filsafat adalah pengetahuan yang berusaha menyelidiki segala sesuatu yang ada dan yang mungkin ada dengan menggunakan pikiran. Filsafat memiliki bidang- bidang kajiannya mencakup berbagai disiplin ilmu antara lain:

a. Metafisika: Penyelidikan dibalik alam yang nyata

b. Kosmologi: penyelidikan tentang alam (filsafat alam)

c. Logika: pembahasan tentang cara berfikir cepat dan tepat

d. Etika: Pembahasan tentang tingkah laku manusia

e. Theolica: Pembahasan tentang ketuhanan

f. Antropolog: pembahasan tentang manusia ${ }^{13}$

Dengan demikian, jelaslah bahwa etik atau akhlaq termasuk salah satu komponen dalam filsafat. Banyak ilmu- ilmu yang pada mulanya merupakan bagian filsafat karena ilmu tersebut kian meluas dan berkembang akhirnya membentuk disiplin ilmu tersendiri dan terlepas dari filsafat. Demikian juga dengan etika atau akhlak, dalam proses perkembangannya, sekalipun masih diakui sebagian bagian dalam pembahasan filsafat, kini telah merupakan ilmu yang mempunyai identitas sendiri.

Pada awal pengkajiannya, bangsa Arab masih sedikit yang menyelidiki akhlak berdasar ilmu pengetahuan. Karena mereka telah merasa puas mengambi akhlak dari agama, dan tidak merasa butuh kepada penyelidikan ilmiah mengenai dasar baik dan buruk. Karena agama adalah menjadi dasar kebanyakan buku- buku yang ditulis dalam akhlak seperti yang kita lihat dalam bukunya al- Ghazali dan alMawardi. ${ }^{14}$

Orang Arab yang melakukan penyelidikan tentang akhlak dengan dasar ilmu pengetahuan ialah Abu Nasr al Farabi. Disamping itu ada Ikhwanus Sofa dan Abu Ali Ibnu Sina. Mereka telah mempelajari filsafat- filsafat Yunani, terutama pendapat- pendapat bangsa Arab yang terbesar mengenai akhlak ialah Ibnu Miskawaih. Dia telah mencampurkan ajaran Plato, Aristoteles, Galinus dengan ajaran- ajaran Islam. ${ }^{15}$

Seperti ilmuwan lainnya pada era abad ke- $4 \mathrm{H}$ dan ke-5 atau abad ke 10 dan 11 M, Ibnu Miskawaih merupakan tokoh filosofi muslim yang mempunyai wawasan luas, pendekatan kajian filsafatnya dengan mengadopsi filsafat filsafat

\footnotetext{
${ }^{13}$ Nasrul, Akblak Tasawwuf, (Yogyakarta: Aswaja Pressindo: 2015), hlm. 10

${ }^{14}$ H.A. Mustofa, Akblak Tasawwuf ( Bandung: Pustaka Setia, 2017) hlm.50

${ }^{15}$ Ibid.
}

22 | FALASIFA, Vol. 10 Nomor 1 Maret 2019 
Yunani yang diterjemahkan dalam bahasa Arab. Walaupun filosofi yang diterapkannya khusus untuk masalah- masalah Islam, ia jarang menggunakan agama untuk mengubah filosofi, ia cenderung menunjukkan filsafat Islam dengan menyesuaikan Islam kedalam sistem praktik rasional yang lebih luas bagi semua manusia. Oleh sebab itu, tidak heran jika beliau dikenal sebagai seorang humanis Islam.

Pengertian Akhlak menurut Ibnu Miskawaih adalah Akhlak sebagai bentuk jama' dari Khuluq, yaitu keadaan jiwa yang mendorong untuk melakukan perbuatan-perbuatan tanpa memerlukan pemikiran dan pertimbangan. ${ }^{16}$

Menurut Ibnu Miskawaih manusia terdiri dari dua substansi; pertama substansi yang berupa tubuh (al-jism) sebagai wawasan materi, dan yang kedua jiwa (al-nafs) substansi yang tidak berdemensi sebagai wawasan immateri dan inilah esensi manusia, jiwa bukan tubuh, bukan bagian dari tubuh, bukan pula keadaan dalam tubuh, tetapi sesuatu yang lain dengan tubuh, baik dari segi substansinya, penilaiannya, sifat-sifat serta tingkah lakunya. ${ }^{17}$

Kesempurnaan manusia akan dicapai apabila manusia itu sendirimampu menyeimbangkan dari tiga unsur kekuatan jiwa yaitu: ${ }^{18}$

a. Quwwat al-Natiqah (daya pikir) merupakan fungsi jiwa tertinggi,kekuatan berpikir, melihat fakta, alat yang digunakan adalah otak. Bilakekuatan jiwa ini normal dan tidak bergeser dari hakekatnya akan lahirkeutamaan ilmu dan alhikmah (kebijakan) jiwa pikir kritis analitisuntuk mengetahui segala yang ada.

b. Quwwat al-Ghadabiyah (daya marah) keberanian menghadapi resiko,ambisi pada kekuasaan, kedudukan dan kehormatan alat yang digunakanhati. Kekuatan jiwa ini seimbang di bawah kontrol daya aqliyah akanmenghasilkan keutamaan al-Hilm (kesantunan) dan diikuti fadilah alsaja'ah (keberanian).

c. Quwwat al-Shahwiyyah (nafsu) atau bisa disebut juga quwwat albahimiyah (daya hewani) dorongan nafsu makan, keinginan kepadakelezatan makanan, minuman, seks dan segala sesuatu yangberhubungan dengan kenikmatan inderawi,alat yang digunakan dalambadan manusia adalah perut.

Apabila manusia mampu menyeimbangkan dari ketiga kekuatantersebut maka lahir fadilah-fadilah, artinya ketika daya natiqah normal tidakbergeser dari hakekatnya dan cenderung kepada ilmu pengetahuan yangbenar, maka akan lahir

\footnotetext{
${ }^{16}$ Ibnu Miskawaih, Tahdzib..., hlm.25

${ }^{17}$ Ibn Miskawaih, Menuju kesempurnaan Akblak, (Terj) Helmi Hidayat, (Bandung: Mizan,1997), hlm.39

${ }^{18}$ Ramli, Pendidikan dan Ilmu Pengetahuan Dalam Upaya Mencari Format Pendidikan yang Islami Kajian Pemikiran Ibmu Miskawaib), Jurnal el- Furqonia Vol. 1 nomor 01 Agustus 2015, hlm. 175
} 
fadilah al-ilm lalu al-hikmah. Begitu juga ketikakekuatan bahimiyah mampu dikontrol oleh daya natiqah artinya tidak larutdalam kekuatan hawa nafsu maka akan timbul iffah (kebersihan diri) dan alsakha'u(kedermawanan). Kemudian yang terakhir yaitu bila kekuatanghadabiyah seimbang di bawah kontrol jiwa natiqah, maka timbul fadilah albilm (kesantunan) dan al-saja'ah (keberanian).

Pada intinya, Ibnu Miskawaih memandang manusia mempunyai tiga fakultas yaitu fakultas nafsu, marah, dan pikir, ${ }^{19}$ di mana yang menjadi hakikatnya adalah fakultas pikirnya. ${ }^{20}$ Konsep akhlaknya yaitu doktrin jalan tengah sebagai dasar keutamaan akhlak ${ }^{21}$ yaitu arif, sederhana (yang diiringi sifat dermawan), berani (yang diiringi sifat sabar), dan adil. ${ }^{22}$ Tujuanpendidikan akhlahknya yaitu terwujudnya sikap batin yang mampu mendorong secaraspontan bagi terciptanya semua perbuatan yang bernilai baik, sehingga mencapaikesempurnaan (teoritis dan praktis) dan memperoleh kebahagiaan yang sempurna (alsa'ādah), ${ }^{23}$ mengendalikan fakultas nafsu dan fakultas marah itu patuh kepada akal dansyariat, ${ }^{24}$ kemudian diiringi kerjasama (hidup) dengan masyarakat ${ }^{25}$ dan kenikmatan(spiritual) di dalam menjalankan berbagai akhlak mulia. ${ }^{26}$ Metode pendidikan akhlaknyayaitu alami, ${ }^{27}$ pembiasaan, riy $\bar{a} d a h^{28}$ dan mijāhadah. Materi

${ }^{19}$ Ibn Miskawaih, Memiju Kesempumaan Akblak, terj. Hemi Hidayat (Bandung: Mizan, 1997),hlm. 44.

${ }^{20}$ Halimatus Sa'diyah, "Konsep Pendidikan Akhlak Perspektif Ibn Miskawaih", Tadris, Volume6 Nomor 2 (Desember), 2011, hlm. 270-271. Manusia mencapai kemanusiaannya dan mensejajarkandirinya dengan Malaikat, serta berbeda dengan binatang, berkat fakultas yang paling baik ini, yaitufakultas berpikir (rasional). Ibn Miskawaih, Menuju, hlm. 68.

${ }^{21}$ Seperti halnya Plato (427-347 SM), Aristoteles (384-322 SM), dan filosof Muslim seperti Al- Kindi dan Ibn Sinā juga memiliki paham doktrin jalan tengah. Ibid., hlm. 270-271.

${ }^{22}$ Ibn Miskawaih, Menuju, hlm. 44.

${ }^{23}$ Halimatus Sa'diyah, "Konsep", hlm. 272-273. Kesempurnaan teoritis berkenaan dengan kesempurnaan praktis seperti bentuk dan materi. Yang satu tidak akan lengkap kecuali bila ditunjang oleh yang lainnya, karena pengetahuan (teoritis) adalah permulaannya dan perbuatan (praktis) itu adalah akhirannya. Lihat, Ibn Miskawaih, Menuju, hlm. 64.

${ }^{24}$ Ibn Miskawaih, Menuju, hlm. 44.

${ }^{25}$ Ibid., hlm. 64.

${ }^{26} \mathrm{Ibid}$., hlm. 65

${ }^{27}$ Metode alami adalah cara berupa menemukan fakultas-fakultas dalam diri (manusia) yang muncul lebih dahulu, kemudian memulai memperbaruinya. Setelah itu, dilanjutkan pada fakultas-fakultas yang muncul, kemudian mengikuti tatanan alami. Ibid., hlm. 60

${ }^{28}$ Halimatus Sa'diyah, “Konsep”, hlm. 275.

24 | FALASIFA, Vol. 10 Nomor 1 Maret 2019 
pendidikan akhaknya yaituilmu syariat, ilmu akhlak dan ilmu nalar. ${ }^{29}$ Kewajiban mendidik anak pertama kali adalah orang tuanya, karena anak yang baru lahir masih bersih (suci). Selanjutnya, dia berpendapat bahwa lingkungan dapat mempengaruhi tumbuhnya akhlak seseorang. ${ }^{30}$

\section{Tujuan Pendidikan Akhlak Menurut Ibnu Miskawaih}

Ibnu Miskawaih mengatakan bahwa tujuan pendidikan akhlak adalah terwujudnya sikap batin yang mampu mendorong manusia secara spontan untuk melakukan tingkah laku yang baik, sehingga ia berprilaku terpuji, mencapai kesempurnaan sesuai dengan substansinya sebagai manusia, dan memperoleh kebahagiaan (as-sa "adab) yang sejati dan sempurna. ${ }^{31}$

Kesempurnaan manusia menurut Ibnu Miskawaih ada dua macam karena ada fakultas yang dimilikinya yaitu fakultas kognitif dan fakultas praktis. Kalau seseorang menguasai kedua bagian ini maka ia akan memperoleh kebahagiaan puncak. Kesempurnaan manusia yang terdiri dari bagian yaitu melalui :

a. Fakultas Kognitif yaitu dengan fakultas ini akan memunculkan pengetahuan terwujudlah bila mendapatkan pengetahuan sedemikian sehingga persepsinya, wawasan dan kerangka berpikirnya akurat. Dengan demikian dia tidak akan melakukan dalam kesalahan dalam keyakinannya dan tidak meragukan suatu kebenaran. Dengan mengetahui maujud-maujud, dimana dia bergerak maju secara sistematis, dia mencapai pengetahuan ilahi yang merupakan pengetahuan tertinggi tingkatannya. Pada pengetahuan ilahi inilah dia berpegang teguh jiwanya tentram, hatinya tenang, keraguannya hilang dan tampak jelas obyek terakhir yang diinginkannya didepan matanya sampai dia bersatu dengannya. Ini juga disebut dengan cara kesempurnaan dimana ia akan memperoleh pengetahuan yang sempurna.

b. Fakultas Praktis yaitu kesempurnaan karakter dimulai dari menertibkan fakultas dan aktivitas yang khas bagi fakultas itu sehingga tidak saling berbenturan namun hidup harmonis didalam dirinya sehingga seluruh aktivitas sesuai dengan fakultas lihatnya dan tertata dengan baik diakhiri dengan penataan kehidupan sosial, dimana tindakan dikalangan masyarakat terjadi keselarasan dan masyarakat mencapai kebahagiaan seperti yang terjadi pada individu manusia. ${ }^{32}$

\footnotetext{
${ }^{29}$ Ibn Miskawaih, Meniju., hlm. 59-60.

${ }^{30}$ Ibid., hlm. 76.

${ }^{31}$ Ibnu Miskawaih, Tahdzib al-Akblak, (Bairut, Libanon: Daar al-Kutub al„Ilmiyyah, 1985), hlm. 30-31.

${ }^{32}$ Nisrokha, Membongkar Konsep Pendidikan Akblak...,hlm. 115
}

FALASIFA, Vol. 10 Nomor 1 Maret 2019 | 25 
Ifa Afidah

\section{KESIMPULAN}

Pengertian Akhlak menurut Ibnu Miskawaih adalah Akhlak sebagai bentuk jama' dari Khuluq, yaitu keadaan jiwa yang mendorong untuk melakukan perbuatan-perbuatan tanpa memerlukan pemikiran dan pertimbangan. tujuan pendidikan akhlak adalah terwujudnya sikap batin yang mampu mendorong manusia secara spontan untuk melakukan tingkah laku yang baik, sehingga ia berprilaku terpuji, mencapai kesempurnaan sesuai dengan substansinya sebagai manusia, dan memperoleh kebahagiaan (as-sa"adah) yang sejati dan sempurna. Kesempurnaan manusia tersebut akan dicapai apabila manusia itu sendiri mampu menyeimbangkan dari tiga unsur kekuatan jiwa, yaitu; Quwwat al-Natiqah (daya pikir), Quwwat al-Ghadabiyah (daya marah), dan Quwwat al-Shahwiyyah (nafsu).

\section{DAFTAR PUSTAKA}

Abdul Mujib dan Muhaimin Tadjab, Dimensi Studi Islam, (Surabaya : Abdi Tama, 1994

Ary Nilandari, Memahat Kata, Memugar Dunia:101 Kisah yang Menggugah Pikiran, (Bandung: Penerbit MLC, 2005)

Depag RI, Alquran dan Terjemahan, (Jakarta; Pt. Sygma Examedia Arkanleema, 2009)

H.A. Mustofa, Akblak Tasawwuf ( Bandung: Pustaka Setia, 2017)

Halimatus Sa'diyah, "Konsep Pendidikan Akhlak Perspektif Ibn Miskawaih", Tadris, Volume 6 Nomor 2 Desember 2011

Harun Nasution, Filsafat dan Mistisisme dalam Islam (Jakarta: Bulan Bintang, 1973)

https://www.google.com/amp/s/m.republika.co.id/amp/52731 tentang Ibnu Miskawaih, bapak etika Islam (28 mei 2009)

Ibn Miskawaih, Menuju kesempumaan Akblak, (Terj) Helmi Hidayat, (Bandung: Mizan, 1997)

Ibn Miskawaih, Tahdzib al-Akblak, (Beirut : Darul al-Kutub al-Ilmiah, 1985)

M..M. Syarif, (Ed.), The History of Muslim Philosophy, ( New York: Dover Publications, 1967)

Maftuhin, Filsafat Islam, (Yogyakarta: Teras, 2012)

Nasrul, Akblak Tasawwuf, (Yogyakarta: Aswaja Pressindo: 2015)

Nisrokha, Membongkar Konsep Pendidikan Akblak Ibnu Miskawaih, Jurnal Madaniyah, Volume 1 Edisi X Januari 2016

Nurkhalis Madjid, Islam Doktrin dan Peradaban, (Jakarta: Paramadina, 2008)

Ramli, Pendidikan dan Ilmu Pengetahuan Dalam Upaya Mencari Format Pendidikan yang Islami Kajian Pemikiran Ibmu Miskawaih), Jurnal elFurqonia Vol. 1 nomor 01 Agustus 2015

Sirojuddin Zar, Filsafat Islam (Filosof dan Filsafatnya), (Jakarta: Rajawali Press, 2017)

26 | FaLASIFA, Vol. 10 Nomor 1 Maret 2019 